Jpn. J. Phys. Fitness Sports Med. 2009, 58: 405 408

\title{
【Short Communication】
}

\section{LIPOPOLYSACCHARIDE-INDUCED TUMOR NECROSIS FACTOR (TNF)- $\alpha$ PRODUCTION DEPENDS ON EXERCISE INTENSITY IN RATS}

\author{
Hiromi Kitamura ${ }^{1)}$, Kumiko Minato ${ }^{1)}$, MASAKi Kimura ${ }^{2)}$, \\ HIDEKI YAMAUCHI ${ }^{3)}$ and HIROMI YANO ${ }^{4}$
}

key words : exercise intensity, pro-inflammatory cytokines, catecholamines

\section{I . Introduction}

Acute prolonged and/or high-intensity exercises suppress immune response ${ }^{1-3)}$. In fact, we and others reported that strenuous exercise reduces plasma tumor necrosis factor (TNF) $-\alpha$ levels in response to lipopolysaccharide (LPS), which is a component of the cell wall of gram-negative bacteria ${ }^{4,5)}$. The relationship between exercise intensity and the suppression of TNF- $\alpha$ in response to LPS is not fully understood.

It is known that catecholamines inhibit LPS-induced $\mathrm{TNF}^{-} \alpha$ production $^{6)}$ and its release depends on exercise intensity $^{7)}$. Recently, we reported that the $\beta$ adrenergic receptor blocker almost completely reversed strenuous exercise-induced suppression of TNF $-\alpha$ in response to LPS ${ }^{4)}$. Accordingly, we made a hypothesis that the suppression of LPS-induced TNF- $\alpha$ production after exercise depends on exercise intensity via catecholamines. Here we studied the effects of different exercise intensities on LPS-induced $\mathrm{TNF}-\alpha$ production in rats.

\section{II . Methods}

\section{A. Animals}

Female 10-week old F344 rats (Charles River Laboratories Japan, Kanagawa, Japan) were used in this experiment. The rats were housed in a controlled environment $\left(20 \pm 1^{\circ} \mathrm{C}, 12: 12\right.$-hour light-dark cycle) and allowed unrestricted access to standard rat chow (Oriental Yeast Co., Tokyo, Japan) and tap water. Before the experiment, all rats were run on a treadmill at $15 \mathrm{~m} / \mathrm{min}$ for $15 \mathrm{~min}$ on a $15 \%$ grade during a $3-$ day acclimation period. The institutional animal care and usage committee of the Wayo Women's University approved the experiment. The experimental procedures followed the guidelines set forth in the Care and Use of Animals in the Field of Physiological Sciences approved by the Council of the Physiological Society of Japan.

\section{B. Experimental design}

The rats were randomly assigned to four groups; sedentary (Rest; $n=18$ ), low-intensity exercise $(\mathrm{L}-\mathrm{Ex} ; \mathrm{n}=8)$, moderate-intensity exercise $(M-E x ; n$ $=8)$ and high-intensity exercise ( $\mathrm{H}-\mathrm{Ex} ; \mathrm{n}=7)$ groups. L-Ex, M-Ex and H-Ex rats ran at a speed of 10, 21 and $26 \mathrm{~m} / \mathrm{min}$, respectively. All exercised rats ran on

\footnotetext{
1) 和洋女子大学生活科学系運動生理学研究室 干272-8533 千葉県市川市国府台 2-3-1

2) 慶應義塾大学薬学部薬物治療学講座 下 105-8512 東京都港区芝公園1-5-30 体力医学研究室

干182-8570 東京都調布市国領町8-3-1

4) 川崎医療福祉大学健康体育学科 干710-0193 岡山県倉敷市松島288
}

3) 東京慈恵会医科大学リハビリテーション医学講座 Jikei University School of Medicine
体力医学研究室

\author{
Wayo Women's University \\ Keio University \\ Kawasaki University of Medical Welfare
}


a treadmill for $30 \mathrm{~min}$ on a $15 \%$ grade. The running speed of rats were equivalent to exercise intensities of $50 \%, 70 \%$ and $80 \%$ maximal oxygen uptake $\left(\mathrm{VO}_{2}\right.$ $\max )$, as determined in our previous study ${ }^{8)}$. All rested rats were kept in a sedentary condition for $30 \mathrm{~min}$ with no access to food and water. Immediately after exercise or resting periods, all rats received i.v. injections of LPS (Escherichia coli $055: \mathrm{B} 5,1 \mathrm{mg} / \mathrm{kg}$, Sigma-Aldrich Japan, Tokyo, Japan) under the mild anesthesia with ether.

Blood samples were collected from abdominal vein under systemic anesthesia with sodium pentobarbital $(60 \mathrm{mg} / \mathrm{kg}$ i.p.) immediately after exercise or resting periods and 1 hour after LPS injection. Plasma was separated and kept frozen at $-20^{\circ} \mathrm{C}$ until later measurement of stress hormones and TNF- $\alpha$ was taken.

\section{Assay for Stress Hormones and TNF- $\alpha$}

The blood samples taken immediately after exercise or resting periods were measured for plasma stress hormones at a commercial laboratory (SRL, Inc. Tokyo, Japan). Plasma adrenaline, noradrenaline and dopamine were measured using automated HPLC ${ }^{9}$. Plasma corticosterone was determined by RIA ${ }^{10}$. The blood samples taken 1 hour after LPS injection were measured for plasma TNF- $\alpha$ using a commercially available ELISA kit (BioSource International, Camarillo, CA).

\section{Statistics}

Data are expressed as mean \pm standard error of the mean (SEM), and analyzed using an analysis of variance (ANOVA) procedure by Fisher's protected least-significant difference (PLSD) test for post hoc analyses (by StatView for Windows Ver. 5.0, SAS Institute Inc. Cary, NC). $\mathrm{P}<0.05$ was considered as statistically significant.

\section{III . Results and discussion}

Although previous investigations indicated that exhaustive exercise inhibits the augmentation of LPS-induced TNF- $\alpha$ production ${ }^{4,5)}$, the relationship between exercise intensity and the suppression of LPS-induced TNF- $\alpha$ production has not been clar-

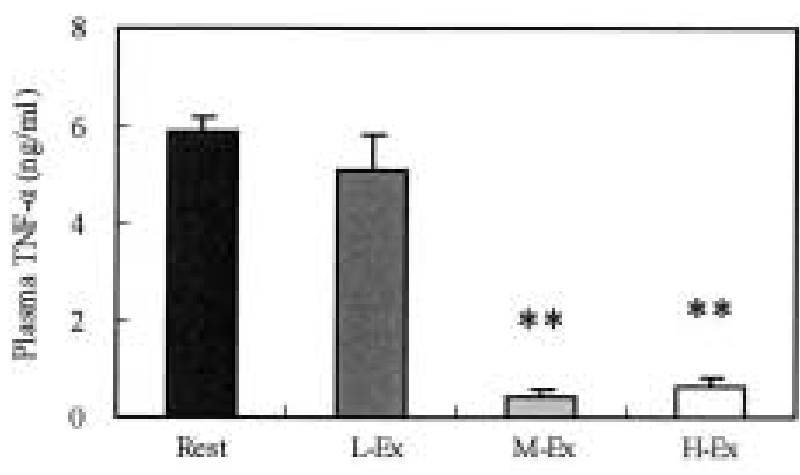

Fig. 1. Effects of different exercise intensities on plasma levels of LPS-induced TNF- $\alpha$. Data are expressed as mean \pm standard error of the mean(SEM). Statistical analyses were performed using an analysis of variance (ANOVA) procedure. Fisher's protected least-significant difference(PLSD) test was used for post hoc analyses. p values of $<0.05$ were considered statistically significant. $* * p<0.01$, as compared with Rest and L-Ex groups.

ified. In this study, we found no difference between Rest and L-Ex groups in plasma levels of LPS-induced TNF- $\alpha$ (Fig. 1 ). In contrast, plasma levels of LPSinduced TNF- $\alpha$ in both $\mathrm{M}-\mathrm{Ex}$ and $\mathrm{H}-\mathrm{Ex}$ groups were significantly lower than Rest and L-Ex groups ( $<<$ 0.01 , respectively). There was no significant difference in plasma levels of LPS-induced TNF- $\alpha$ between $M-E x$ and $H-E x$ groups. Thus, more than moderate exercise $\left(>70 \% \mathrm{VO}_{2} \max \right)$ was shown to be effective in the suppression of LPS-induced TNF- $\alpha$ production.

Prolonged and/or exhaustive exercise increases stress hormones ${ }^{7,8)}$, which induces immunosuppres$\operatorname{sion}^{6,11)}$. In this study, we clarified whether moderate $^{-}$and high-intensity exercise also increases these hormones or not. Plasma stress hormones levels are summarized in Table 1. No significant differences in plasma corticosterone levels among the four groups were found. Bagby et al. ${ }^{5)}$ reported one possibility that glucocorticoids would play a role in the exerciseinduced reduction in TNF- $\alpha$ in response to LPS. However our previous study found that exhaustive exercise-induced suppression of plasma TNF- $\alpha$ after LPS injection did not reverse with the adminis. tration of the glucocorticoids receptor antagonist $\mathrm{RU} 486^{4)}$. We suggest that corticosterone is not in- 
volved in the exercise mediated suppression of TNF$\alpha$ production.

In contrast, plasma adrenaline and dopamine levels in $\mathrm{M}-\mathrm{Ex}$ and $\mathrm{H}-\mathrm{Ex}$ groups were significantly higher than Rest and L-Ex groups. In addition, high plasma noradrenaline levels were also observed in $\mathrm{H}-\mathrm{Ex}$ group. From these results, catecholamines were found to be induced by moderate- and high-intensity exercise. Therefore exercise-induced catecholamines are responsible for the moderate- and high-intensity exercise-induced suppression of LPS-induced TNF$\alpha$ production. In fact, it was reported that pre ${ }^{-}$ treatment of rats with the $\beta$-adrenergic receptor blocker completely reversed an exhaustive exerciseinduced suppression of plasma $\mathrm{TNF}-\alpha$ in response to LPS ${ }^{4)}$. Although we did not measure plasma interleukin (IL) -6 levels, Starkie et al. ${ }^{12)}$ indicated the possibility of IL- 6 inhibiting endotoxin-induced TNF- $\alpha$ production. Exercise-induced suppression of LPS-induced TNF- $\alpha$ production might be influenced by not only catecholamines but also IL-6.

Our study showed that moderate-intensity exercise attenuated the production of pro-inflammatory cytokine in response to pathogens. Numerous reports have shown that moderate exercise increases the antiviral $^{13)}$ and phagocytic functions ${ }^{14)}$. Thus, moderate exercise might attenuate inflammation and maintain other immune functions. On the other hand, Dhabhar et al. have suggested that under conditions of acute stress, just as the stress response prepares the nervous, neuroendocrine, and other systems for fight or flight, it may also prepare the immune system for challenges (e.g., wounding or infection) which may be imposed by the stressor ${ }^{15)}$. Therefore, our observations suggest the postponement of acute inflammation required for elimination of bacteria and regeneration of tissues from wounds and injuries that compromises physical performance. Further studies are required to examine the cellular mechanisms by which pro-inflammatory cytokine is attenuated.

\section{IV . Conclusions}

Moderate- and high-intensity exercise was shown to suppress LPS-induced TNF- $\alpha$ production. Thus inflammatory reaction against bacterial invasion may be modified depending on exercise intensity via catecholamines.

\section{V . Acknowledgement}

This study was supported by a grant from the Interdepartmental Research Fund of Wayo Women's University to H. Kitamura.

(Accepted Apr. 28, 2009)

\section{References list}

1) Pedersen, B. K., Ullum, H. NK cell response to physical activity: possible mechanisms of action. Med. Sci. Sports Exerc., (1994), 26, 140-146.

2) Woods, J. A., Davis, JM., Smith, J. A., Nieman, D. C. Ex-

Table 1. Plasma stress hormones levels in resting and different exercised groups.

\begin{tabular}{cllll}
\hline Group & $\begin{array}{l}\text { Corticosterone } \\
(\mathrm{ng} / \mathrm{ml})\end{array}$ & $\begin{array}{l}\text { Adrenaline } \\
(\mathrm{ng} / \mathrm{ml})\end{array}$ & $\begin{array}{l}\text { Noradrenaline } \\
(\mathrm{ng} / \mathrm{ml})\end{array}$ & $\begin{array}{l}\text { Dopamine } \\
(\mathrm{ng} / \mathrm{ml})\end{array}$ \\
\hline Rest & $973 \pm 44$ & $2.8 \pm 0.4$ & $0.4 \pm 0.1$ & $0.04 \pm 0.01$ \\
L-Ex & $990 \pm 50$ & $4.6 \pm 1.1$ & $0.7 \pm 0.2$ & $0.03 \pm 0.00$ \\
M-Ex & $1145 \pm 26$ & $7.2 \pm 0.7 *$ & $0.5 \pm 0.0$ & $0.10 \pm 0.01 * *$ \\
H-Ex & $1093 \pm 245$ & $8.3 \pm 1.4 * *$ & $3.9 \pm 1.3 * * \dagger \dagger$ & $0.13 \pm 0.03 * *$ \\
\hline
\end{tabular}

Data are expressed as means \pm SEM. ${ }^{*} \mathrm{p}<0.05, *_{\mathrm{p}}^{*}<0.01$, as compared with Rest and L-Ex groups. ${ }^{\dagger \dagger} \mathrm{p}<0.01$, as compared with M-Ex groups. 
ercise and cellular innate immune function. Med. Sci. Sports Exerc., (1999), 31, 57-66.

3) Davis, J. M., Kohut, M. L., Colbert, L. H., Jackson, D. A., Ghaffar, A., Mayer, E.P. Exercise, alveolar macrophage function, and susceptibility to respiratory infection. J. Appl. Physiol., (1997), 83, 1461-1466.

4) Kitamura, H., Shiva, D., Woods, J.A., Yano, H. Beta-adrenergic receptor blockade attenuates the exercise-induced suppression of TNF-alpha in response to lipopolysaccharide in rats. Neuroimmunomodulation, (2007), 14, 91-96.

5) Bagby, G. J., Sawaya, D. E., Crouch, L. D., Shepherd, R.E. Prior exercise suppresses the plasma tumor necrosis factor response to bacterial lipopolysaccharide. J. Appl. Physiol., (1994), 77, 1542-1547.

6) Röntgen P, Sablotzki A, Simm A, et al.: Effect of catecholamines on intracellular cytokine synthesis in human monocytes. Eur. Cytokine Netw., (2004), 15, 14-23.

7) Scheurink, A. J., Steffens, A. B., Bouritius, H., Dreteler, G. H., Bruntink, R., Rernie, R., Zaaqsm, J. Adrenal and sympathetic catecholamines in exercising rats. Am. J. Physiol., (1989), 256, R155-R160.

8) Yano, H., Kinoshita, S., Yano, L. Relationship between oxygen uptake and work performance of female Fischer 344 rats in response to treadmill exercise. Kawasaki J. Med. Welf., (1996), 2, 153-155.
9) Yano, L., Yano, H., Taketa, K. Portal blood flow during and after high-intensity physical exercise in rats: response of plasma endotheline-1 and catecholamine. Hepatol. Res., (1998), 11, 1-11.

10) Nabors, C. J., West, C. D., Mahaian, D. K., Tyler, F. H. Radioimmunoassay of human plasma corticosterone: method, measurement of episodic secretion and adrenal suppression and stimulation. Steroids, (1994), 23, $363-378$.

11) Elenkov, I. J., Chrousos, G. P. Stress hormones, proinflammatory and anti-inflammatory cytokines, and autoimmunity. Ann. NY Acad. Sci., (2002), 966, 290-303.

12) Starkie, R., Ostrowski, S. R., Jauffred, S., Febbraio, M., Pedersen, B.K. Exercise and IL-6 infusion inhibit endotoxin-induced TNF-alpha production in humans. FASEB J., (2003), 17, 884-886.

13) Lowder, T., Padgett, D. A., Woods, J. A. Moderate exer. cise protects mice from death due to influenza virus. Brain Behav. Immun., (2005), 19, 377-380.

14) Yano, H., Kinoshita, S., Kira, S. Effects of acute moderate exercise on the phagocytosis of Kupffer cells in rats. Acta Physiol. Scand., (2004), 182, 151-160.

15) Dhabhar, F. S., and McEwen B.S. Acute stress enhances while chronic stress suppresses cell-mediated immunity in vivo: a potential role for leukocyte trafficking. Brain Behav. Immun., (1997), 11, 286-306. 